\title{
Kajian strategis dan prioritas pembangunan pendidikan menengah untuk meningkatkan mutu pendidikan di Pulau Madura
}

\author{
Strategic studies and secondary education development priorities \\ to improve the quality of education in Madura Island
}

\author{
Priyono Tri Febrianto dan Sulaiman \\ Fakultas Ilmu Pendidikan, Universitas Trunojoyo, Bangkalan, Madura \\ Jalan Raya Telang Kamal Bangkalan, Jawa Timur, Indonesia \\ E-mail: priyono.febrianto@trunojoyo.ac.id
}

\begin{abstract}
Efforts in quality improvement and development of education in the era of regional autonomy are not only the responsibility of the central government and provincial governments, but also the responsibility of local governments. Quality improvement and development of education thus become strategic issues for any local government. This study aims to address issues related to: (1) the condition of school facilities and infrastructure (2) the role of school committees which is not optimal; (3) the absence of equitable distribution of teachers; and (4) the lack of Information and Communication Technology/ICT-based learning application in in secondary schools. The research was conducted in four districts, namely Bangkalan, Sampang, Pamekasan and Sumenep. The main theory employed in this study is the School Based Management (SBM) or the so-called School Based Management (SBM). The population was students, parents and teachers. The total number of samples was 250 people comprising 100 students, 100 parents and 50 teachers. The research data were obtained from primary and secondary data. The study yielded a number of key findings. First, $90 \%$ of High School (or its equivalent) teachers master the materials taught. This is due to fact that the materials taught are in accordance with the education qualification of the teacher. Secondly, the mismatch found in Madurese high schools was apparently caused by the lack of educators with suitable qualification for the subjects they teach concurrently. Almost all secondary teachers in Madura island require trainings related to the development of competency for mastering the subject materials. The last but not the least, the majority of teachers still apply simple learning methods. Although the method applied by teachers are generally similar, there are significant differences between the favorite schools and the other schools.
\end{abstract}

Keywords: school autonomy, quality of education, school-based management

\begin{abstract}
Abstrak
Upaya peningkatan mutu dan pembangunan bidang pendidikan di era otonomi daerah bukan hanya merupakan tanggung jawab pemerintah pusat maupun pemerintah provinsi, melainkan juga merupakan tanggung jawab pemerintah daerah. Oleh karena itu, upaya peningkatan mutu dan pembangunan bidang pendidikan menjadi isu strategis bagi setiap pemerintah daerah. Penelitian ini bertujuan untuk menjawab permasalahan berkaitan dengan: (1) kondisi sarana dan prasarana sekolah (2) peran komite sekolah belum optimal; (3) belum adanya pemerataan tenaga guru yang proporsional; (4) belum diterapkannya pembelajaran berbasis Teknologi Informasi dan Komunikasi (TIK) di sekolah menengah. Penelitian ini dilakukan di empat kabupaten, yaitu Kabupaten Bangkalan, Sampang, Pamekasan dan Sumenep. Teori utama penelitian ini adalah School Based Management $(S B M)$ atau yang disebut dengan Manajemen Berbasis Sekolah (MBS). Populasinya adalah siswa, orangtua dan guru. Jumlah sampel yang diambil sebanyak 250 orang, terdiri dari 100 siswa, 100 orang tua, dan 50 guru. Data penelitian ini diperoleh dari data primer dan data sekunder. Temuan pokok dalam penelitian ini adalah sebagai berikut: $90 \%$ guru Sekolah Menengah Atas atau sederajat menguasai materi pelajaran yang diajarkan. Hal ini disebabkan materi yang diajarkan telah sesuai dengan klasifikasi pendidikan yang dimiliki oleh guru yang bersangkutan. Adanya mismatch dalam dunia pendidikan SMA di Madura disebabkan kurangnya tenaga pendidik yang berasal dari jurusan yang dirangkap. Hampir semua guru menengah di wilayah Pulau Madura memerlukan pelatihan atau diklat yang berkaitan dengan pengembangan kompetensi penguasaan materi pembelajaran. Sebagian besar guru masih menerapkan metode pembelajaran yang sangat sederhana. Secara umum metode yang diterapkan guru sama, akan tetapi terdapat perbedaan yang sangat signifikan antara sekolahsekolah favorit dan sekolah lainnya.
\end{abstract}

Keywords: otonomi sekolah, mutu pendidikan, manajemen berbasis sekolah 


\section{Pendahuluan}

Sebagai upaya meningkatkan mutu sumber daya manusia untuk mengejar ketertinggalan di segala aspek kehidupan dan menyesuaikan dengan perubahan global serta perkembangan ilmu pengetahuan dan teknologi, pemerintah pada tanggal 11 Juni 2003 telah mengesahkan Undang-undang Sistem Pendidikan Nasional yang baru, sebagai pengganti Undang-undang Sisdiknas Nomor 2 Tahun 1989. Undang-undang Sisdiknas Nomor 20 Tahun 2003 yang terdiri dari 22 Bab dan 77 pasal tersebut juga merupakan pengejawantahan dari salah satu tuntutan reformasi yang marak sejak tahun 1998. Perubahan mendasar yang dicanangkan dalam Undang-undang Sisdiknas yang baru tersebut antara lain adalah demokratisasi dan desentralisasi pendidikan, peran serta masyarakat, tantangan globalisasi, kesetaraan dan keseimbangan, jalur pendidikan, dan peserta didik. Hal itu juga sejalan dengan pendapat Mastuhu (2007) yang memotret tentang tantangan lembaga pendidikan dalam dua kategori, yaitu tantangan eksternal dan internal, Menata Ulang Pemikiran Sistem Pendidikan Nasional dalam Abad 21 (2003). Kompleksitas mengesankan bahwa sesuatu terjadi secara serentak, sekaligus, dalam waktu yang sama, dan semrawut. Saat ini, semua pihak, terutama para pesaing, pemimpin perusahan, supplier, distributor, ilmuwan, dan pemimpin, berada dan berlomba dalam perubahan yang terus menerus.

Secara umum, Irianto (2011) mengemukakan model pembaruan pendidikan dapat dikelompokkan ke dalam dua model, yaitu top down model dan bottom up model. Penulis memberikan beberapa model antara lain: Broad Based Education (BBE), SBM (School Based Management) dan CBM (Community Based Management). Kebijakan BBE berfokus pada pendekatan pendidikan Life-Skills atau pendidikan kecakapan hidup, yang diikuti oleh kebijakan pengembangan Kurikulum Berbasis Kompetensi (KBK). Kebijakan ini pun berbarengan dengan penerapan model SBM (School Based Management) untuk pendidikan jalur persekolahan dan CBM (Community Based Management) untuk pendidikan jalur luar sekolah. SBM dan CBM dianggap sebagai salah satu model manajemen yang dianggap efektif untuk memberikan kemandirian kelembagaan pendidikan pada jalur sekolah (formal) dan pada jalur luar sekolah (non-formal).

Upaya peningkatan mutu dan pembangunan bidang pendidikan di era otonomi daerah bukan hanya merupakan tanggung jawab pemerintah pusat maupun pemerintah provinsi, melainkan juga merupakan tanggung jawab pemerintah daerah. Oleh karena itu, upaya peningkatan mutu dan pembangunan bidang pendidikan menjadi isu strategis bagi setiap pemerintah daerah. Dengan demikian, harus dilakukan upaya reformasi sekolah dan birokrasi pendidikan. Untuk itu dibuat dan diimplementasikan kebijakan desentralisasi manajemen pendidikan dan otonomi sekolah. Kebijakan desentralisasi pendidikan ini sejalan dengan desentralisasi bidang administrasi pemerintahan, yang memberikan kewenangan yang lebih besar dan banyak (otonom) kepada daerah kabupaten/kota untuk mengurus rumah tangga daerahnya sendiri. Kebijakan desentralisasi manajemen pendidikan dan otonomi pendidikan dasar dan menengah diformulasikan dalam kebijakan manajemen berbasis sekolah (MBS). Menurut Minarti (2011:76) Implementasi Manajemen Berbasis Sekolah (MBS) pada hakikatnya adalah "pemberian otonom yang lebih luas kepada sekolah dengan tujuan akhirnya meningkatkan mutu hasil penyelenggaraan pendidikan sehingga menghasilkan prestasi yang sebenarnya melalui proses manajerial yang mapan melalui peningkatan kinerja dan partisipasi semua stakeholdernya, sekolah pada semua jenjang dan semua jenis pendidikan dengan sifat otonomistiknya tersebut akan menjadi suatu intitusi pendidikan yang organik, demokratik, kreatif, dan inovatif serta unik dengan ciri khasnya untuk melakukan pembaruan sendiri”.

Hal itu selaras dengan pendapat Rohiat (2010:47) bahwa MBS adalah model pengelolaan yang memberikan otonomi (kewenangan dan tanggung jawab yang lebih besar kepada sekolah), memberikan keluwesan kepada sekolah, mendorong partisipasi secara langsung dari warga sekolah (guru, siswa, kepala sekolah, karyawan) dan masyarakat (orang tua siswa, tokoh masyarakat, ilmuwan, pengusaha), dan meningkatkan mutu sekolah berdasarkan kebijakan pendidikan nasional serta peraturan perundang-undangan yang berlaku. Sementara itu, Kustini Hardi (Umiarso dan Imam Gojali 2010:80), menyatakan bahwa penerapan MBS mempunyai tiga tujuan, yaitu: pertama, 
mengembangkan kemampuan kepala sekolah bersama guru dan unsur komite sekolah dalam aspek MBS untuk meningkatkan mutu sekolah. Kedua, mengembangkan kemampuan kepala sekolah bersama guru dan unsur komite sekolah dalam pelaksanaan pembelajaran yang aktif dan menyenangkan, baik di sekolah maupun di lingkungan masyarakat setempat. Ketiga, mengembangkan peran serta masyarakat yang lebih aktif dalam masalah umum persekolahan dari unsur komite sekolah untuk membantu peningkatan mutu pendidikan.

Dengan demikian, pemerintah (pusat) dan pemerintah daerah wajib memberikan layanan dan kemudahan, serta menjamin terselenggaranya pendidikan bermutu bagi warga negara tanpa diskriminasi. Konsekwensinya pemerintah (pusat) dan pemerintah daerah wajib menjamin tersedianya dana guna terselenggaranya pendidikan bagi setiap warga negara yang berusia 7-15 tahun. Itulah sebabnya pemerintah (pusat) dan pemerintah daerah menjamin terselenggaranya wajib belajar, minimal pada jenjang pendidikan dasar tanpa dipungut biaya, karena wajib belajar adalah tanggung jawab negara yang diselenggarakan oleh pemerintah (pusat), pemerintah daerah, dan masyarakat. Dengan adanya desentralisai penyelenggaraan pendidikan dan pemberdayaan masyarakat, maka pendanaan pendidikan menjadi tanggung jawab bersama antara pemerintah (pusat), pemerintah daerah, dan masyarakat. Bahkan, pemerintah (pusat) dan pemerintah daerah bertanggungjawab menyediakan anggaran pendidikan sebagaimana diatur dalam pasal 31 ayat (4) Undang Undang Dasar Negara RI tahun 1945 bahwa Negara memprioritaskan anggaran pendidikan sekurang-kurangnya dua puluh persen dari anggaran pendapatan dan belanja negara serta anggaran pendapatan dan belanja daerah untuk memenuhi kebutuhan penyelenggaraan pendidikan nasional. Itulah sebabnya dana pendidikan, selain gaji pendidik dan biaya pendidikan kedinasan, harus dialokasikan minimal 20\% dari Anggaran Pendapatan dan Belanja Negara (APBN) pada sektor pendidikan, dan minimal 20\% dari Anggaran Pendapatan dan Belanja daerah (APBD). Khusus gaji guru dan dosen yang diangkat oleh pemerintah (pusat) dialokasikan dalam APBN.

Satuan pendidikan yang berbasis keunggulan lokal merupakan paradigma baru pendidikan untuk mendorong percepatan pembangunan di daerah berdasarkan potensi yang dimiliki oleh masyarakat lokal. Dalam hal ini pewilayahan komoditas harus diikuti dengan lokalisasi pendidikan dengan basis keunggulan lokal. Hal ini bukan saja berkaitan dengan kurikulum yang memperhatikan juga muatan lokal, melainkan lebih memperjelas spesialisasi peserta didik, untuk segera memasuki dunia kerja di lingkungan terdekatnya, dan juga untuk menjadi ahli dalam bidang tersebut.

Penelitian ini mengkaji tentang kondisi sarana dan prasarana sekolah, peran komite sekolah, upaya pemerataan tenaga guru yang proporsional dan penerapan pembelajaran berbasis Teknologi Informasi dan Komunikasi (TIK) di sekolah menengah. Hal itu sangat penting untuk memajukan lembaga pendidikan, khususnya di Pulau Madura.

\section{Metode Penelitian}

Analisis data yang digunakan dalam penelitian ini adalah analisis secara deskriptif. Seperti yang diungkapkan oleh Mulyatingsih (2012:38) bahwa analisis secara deskriptif digunakan untuk mendeskripsikan data penelitian apa adanya dan tidak digunakan untuk mengambil simpulan statistik. Penyajian hasil analisis data deskriptif dapat dilengkapi dengan menggunakan tabel, grafik dan diagram (garis, batang, lingkaran). Penyajian data deskriptif bertujuan untuk memberikan gambaran singkat tentang hasil penelitian supaya lebih mudah dibaca dan dipahami.

Data yang dibutuhkan untuk menyusun Rencana Induk Pembangunan Bidang Pendidikan menegah di Madura ini digali melalui beberapa cara. Pertama, untuk memperoleh gambaran tentang kondisi dan situasi problematik di bidang pendidikan menengah di Pulau Madura, selain dari data sekunder di BPS, Dinas Pendidikan, Bappeda, dan dinas terkait, di empat kabupaten yang tersebar di pulau Madura, juga dilakukan penelusuran pada hasil-hasil kajian dan penelitian yang telah dilakukan sebelumnya, tentang permasalahan pendidikan di Provinsi Jawa Timur khususnya di Madura, yaitu Kabupaten Bangkalan, Sampang, Pamekasan dan Sumenep. 
Kedua, melalukan review terhadap berbagai literatur dan studi tentang pendidikan untuk memperoleh gambaran tentang arah dan strategi yang ideal dikembangkan dalam rangka meningkatkan mutu pendidikan menengah di Madura. Review ini penting dilakukan untuk memberoleh kerangka acuan/pemikiran dalam proses penyusunan kebijakan dan strategi pembangunan pendidikan menengah di Madura.

Ketiga, melakukan kajian lapangan untuk mencari masukan langsung dari penyelanggara dan subjek pendidikan, khususnya peserta didik. Wawancara langsung ke lapangan ini penting dilakukan dengan harapan dapat dieliminasi sekecil-kecilnya kemungkinan timbulnya bias dalam menyikapi masalah yang ada.

Informan atau sumber informasi kegiatan pengkajian aspirasi masyarakat Madura di bidang pendidikan ini, meliputi: (1) siswa sebagai subjek utama pendidikan (baik siswa SMA, MA, maupun SMK); (2) Guru di jenjang pendidikan menengah; (3) orang tua siswa atau wali murid sebagai bagian dari warga masyarakat setempat yang terlibat langsung dalam urusan pendidikan anak-anaknya, (4) para pengurus Komite Sekolah, unsur sekolah, tokoh masyarakat, dan jajaran aparat birokrasi pendidikan. Secara keseluruhan, jumlah responden yang diwawancarai dalam kegiatan ini sebanyak 250 orang, terdiri dari 100 siswa, 100 orang tua, dan 50 guru.

Dalam kegiatan ini seluruh data yang berhasil dikumpulkan kemudian diklasifikasi dan dideskripsikan dengan rinci dan sistematis. Sistematika penulisan laporan tidak hanya mendeskripsikan kondisi dan situasi problematik pendidikan menengah di Madura, tetapi juga arah, kebijakan dan strategi yang perlu dikembangkan untuk mempercepat upaya peningkatan kualitas pendidikan menengah di Madura, baik jangka pendek maupun jangka menengah.

\section{Hasil Penelitian dan Pembahasan}

Berdasarkan data guru sekolah menengah (SMA/SMK/MA) di Pulau Madura, hampir 90\% menguasai materi pelajaran yang diajarkan. Hal ini disebabkan materi yang diajarkan telah sesuai dengan klasifikasi pendidikan yang dimiliki oleh guru yang bersangkutan. Misalnya, guru lulusan S1 Matematika, maka dia mengajarkan Matematika. Sekitar 10\% dari mereka yang kurang menguasai materi pelajaran disebabkan materi yang diajarkan tidak sesuai dengan kualifikasi pendidikannya. Hal itu disebabkan kurangnya guru pada lembaga pendidikan yang bersangkutan. Hal itu menyebabkan para guru merangkap beberapa mata pelajaran yang tidak sesuai dengan kompetensi yang dimilikinya. Meskipun demikian, para guru masih mampu mengajarkan materi dengan cukup baik.

Guru yang merangkap mata pelajaran ini terjadi di semua pendidikan menengah di Madura, yaitu: SMA, SMK, dan MA, baik negeri maupun swasta. Kebanyakan guru merangkap mata pelajaran pokok (sesuai dengan klasifikasinya) dengan mata pelajaran pilihan (muatan lokal) seperti Bahasa Inggris, TIK) Teknologi Informasi dan Komunikasi), PLH, maupun keterampilan yang lain. Hal itulah melahirkan mismatch atau guru yang mengajar mata pelajaran yang tidak sesuai dengan latar belakang kualifikasi pendidikan yang dimiliki. Namun, mata pelajaran yang dirangkap merupakan mata pelajaran tambahan seperti Seni Budaya dan TIK. Pada tingkat SMK, terdapat juga guru yang kualifikasinya Biologi mengajar Seni Budaya, guru Olahraga mengajar Kewirausahaan. Pada tingkat MA, guru yang mengajar PAI, juga Sosiologi. Kebanyakan guru SMA merangkap dengan mata pelajaran pokok, bukan mata pelajaran pilihan. Sebenarnya hal ini tidaklah baik bagi pembelajaran karena guru mengajar mata pelajaran yang tidak sesuai dengan keahlian yang dimilikinya. Adanya mismatch dalam dunia pendidikan SMA di Madura disebabkan kurangnya tenaga pendidik yang berasal dari jurusan yang dirangkap. Memang jarang sekali ada guru yang berasal dari lulusan seni, TIK, PLH, maupun muatan lokal yang lain di wilayah ini sehingga mismatch pun tidak dapat dihindarkan.

Berdasarkan hasil analisis angket yang telah disebarkan menunjukkan bahwa hampir semua guru menengah (SMA/SMK/MA) di wilayah Pulau Madura memerlukan pelatihan atau diklat yang 
berkaitan dengan pengembangan kompetensi penguasaan materi pembelajaran. Hal tersebut disebabkan para guru masih kurang memahami teknik, taktik, strategi, dan metode pembelajaran yang baik dan menyenangkan dari materi yang akan diajarkan kepada siswa. Apalagi dengan adanya Kurikulum 2013 yang menuntut para guru lebih aktif, inovatif dan kreatif dalam proses belajarmengajar.

\section{Metode pembelajaran yang diterapkan guru}

Dalam proses pembelajaran terdapat beberapa model pembelajaran yang harus diterapkan oleh guru. Setiap model pembelajaran mempunyai metode yang berbeda antara satu dengan lainnya yang dapat dipilih untuk diterapkan maupun dikolaborasikan. Guru harus menguasai setiap metode pembelajaran. Karena dengan menerapkan metode pembelajaran dalam proses pembelajaran, akan sangat membantu guru menyampaikan materi kepada siswa, dan sebaliknya akan memudahkan siswa dalam memahami materi yang disampaikan oleh guru.

Dari beberapa SMA, MA, dan SMK di Pulau Madura dalam pembelajaran, guru masih menerapkan metode pembelajaran yang sangat sederhana. Secara umum metode yang diterapkan guru sama. Akan tetapi, terdapat perbedaan yang sangat signifikan antara sekolah-sekolah favorit dan sekolah lainnya. Berdasarkan data yang diperoleh rata-rata metode pembelajaran yang digunakan guru sama. Metodemetode tersebut di antaranya adalah metode ceramah, diskusi, praktik, dan tanya jawab. Namun, terdapat beberapa sekolah yang telah menggunakan metode presentasi. Hal ini didukung dengan adanya media LCD proyektor yang dimiliki sekolah. Ada pula siswa yang mengungkapkan bahwa terdapat beberapa guru yang menggunakan metode game dalam mengajar. Hal inilah yang dapat menciptakan pembelajaran lebih aktif dan menyenangkan. Di samping itu, siswa mengungkapkan pendapat yang sangat beragam mengenai kurikulum yang digunakan oleh sekolah. Tidak sedikit pula yang mengungkapkan bahwa mereka tidak tahu mengenai kurikulum yang digunakan oleh sekolah. Siswa hanya mengikuti aturan yang telah ditetapkan oleh guru.

Kondisi iklim pada saat pembelajaran juga sangat baik. Siswa mengungkapkan bahwa suasana pembelajaran membuat mereka dapat belajar dengan tenang dan berkonsentrasi terhadap materi yang dijelaskan oleh guru. Selain metode pembelajaran, terdapat pula kurikulum yang sangat berpengaruh pada keberhasilan proses pembelajaran. Rata-rata siswa mengatakan hanya mengikuti saja kurikulum yang diberikan sekolah. Untuk kurikulum 2013 siswa tidak memahaminya, dan bahkan mereka terkesan menolak dengan sosialisasi kurikulum 2013. Siswa beranggapan bahwa guru kurang memahami kurikulum 2013 sehingga mereka akan mengalami kesulitan jika guru tidak dapat menyampaikan materi dengan baik. Namun, pada dasarnya siswa akan mengikuti perkembangan kurikulum yang ada, asalkan mereka tidak mengalami kesulitan dalam belajar. Dengan demikian, perlu adanya pemahaman yang mendalam dari guru mengenai kurikulum baru, yaitu kurikulum 2013. Salah satu faktor yang mempengaruhi prestasi belajar siswa adalah mata pelajaran. Minat siswa terhadap mata pelajaran yang disukai berbeda-beda. Pada dasarnya semua mata pelajaran mempunyai kelebihan dan kelemahan masing-masing. Akan tetapi, siswa dapat menyukai suatu pelajaran tertentu mulai dari karakteristik mata pelajaran atau tingkat kesulitan mata pelajaran itu sendiri, tingkat penguasaan guru terhadap materi, hingga pembelajaran yang berlangsung inovatif dan kreatif. Seperti yang telihat dalam beberapa SMA/MA/SMK di Pulau Madura mempunyai tingkat kesukaan terhadap mata pelajaran yang berbeda-beda.

Secara umum terdapat perbedaan mata pelajaran yang sangat menonjol antara sekolah umum dengan sekolah kejuruan/khusus. Hal tersebut disebabkan materi ajar yang sangat berbeda di antara keduanya. Ditinjau dari segi karakteristik mata pelajaran atau tingkat kesulitan mata pelajaran, sekolah-sekolah umum rata-rata siswa menyukai mata pelajaran sebagai berikut: a). Bahasa Indonesia menjadi pilihan pertama karena dianggap sebagai mata pelajaran dalam kategori mudah oleh siswa. Selain itu, Bahasa Indonesia merupakan bahasa sehari-hari yang sering digunakan oleh siswa. Jadi, dalam pembelajarannya dianggap mudah dan wajib untuk dipelajari karena merupakan bahasa Nasional Indonesia; b) Seni Budaya jatuh pada pilihan yang kedua. Landasan siswa menyukainya disebabkan materi yang terkandung dalam seni budaya sangat menarik dan tidak hanya sebatas teori-teori saja, 
akan tetapi lebih menekankan pada praktik secara langsung seperti menyanyi, menari, melukis dan lain sebagainya; c) Mata pelajaran Sejarah dianggap sebagai cerminan perjuangan para pahlawan yang telah berjuang demi kemerdekaan Indonesia. Sebagai rasa menghargai terhadap jasa para pahlawan, maka siswa ingin mempelajari mata pelajaran ini dengan baik; d) Mata pelajaran sosiologi dianggap mudah oleh siswa karena mata pelajaran ini membahas tentang interaksi antara manusia. Sehingga sangat perlu dipelajari untuk mengetahui baik dan buruknya perilaku dalam pergaulan remaja; e) Pendidikan jasmani menjadi pilihan siswa yang ketiga karena mata pelajaran ini mengajarkan tentang cara hidup sehat dan cara menjaga kondisi tubuh agar selalu bugar.

Lain halnya dengan SMA. Pada sekolah MA, baik negeri maupun swasta mayoritas mata pelajaran yang disukai rata-rata sama. Mata pelajaran yang disukai di antaranya sebagai berikut: a) Agama Islam banyak disukai oleh siswa karena materi yang terkandung di dalamnya sangat baik digunakan sebagai pedoman hidup mereka. Dengan mempelajari agama Islam, siswa percaya bahwa perilaku mereka akan lebih baik dalam kesehariannya; b) Bahasa Indonesia merupakan bahasa sehari-hari yang digunakan siswa dalam hidup bermasyarakat. Sehingga mereka merasa mudah dan perlu dalam mempelajarinya; c) Selain bahasa nasional, siswa juga menyukai bahasa internasional, utamanya Bahasa Inggris. Mereka mengemukakan alasan yang sangat kuat dalam memilih menyukai mata pelajaran ini. Bahasa Inggris dianggap sebagai bahasa yang mampu membawa siswa pada dunia internasional sehingga mereka tidak merasa tertinggal jika bergaul dengan orang-orang asing.

Sementara itu, rata-rata siswa SMK menyukai mata pelajaran Teknologi Informasi dan Komunikasi (TIK), Biologi, dan Pendidikan Kewarganegaraan (PKN). Alasan mereka di antaranya adalah sebagai berikut: a) Siswa menyukai mata pelajaran TIK disebabkan tidak hanya sebatas teori akan tetapi langsung melakukan praktik. Siswa merasa senang karena mampu menggunakan teknologi yang canggih; b) Materi pembelajaran Biologi berisi tentang alam sekitar sehingga dianggap siswa sangat menarik dipelajari sebagai wujud rasa cinta terhadap lingkungan; c) Mempelajari pendidikan kewarganegaraan dianggap siswa sangat penting karena mempelajari tentang Pancasila dan nasionalisme terhadap bangsa.

Selain karena karakteristik dari mata pelajarannya sendiri. Terdapat faktor lain yang dapat mempengaruhi tingkat kesukaan siswa terhadap mata pelajaran. Tidak cukup dengan karakteristik yang mata pelajaran. Akan tetapi, juga cara penyampaian materi yang dilakukan oleh guru kepada siswa menjadi pengaruh yang sangat besar. Apabila guru dapat menyampaikan materi dengan sangat baik, kreatif, inovatif, dan menyenangkan, tentu siswa akan lebih termotivasi dalam belajar. Seiring dengan berjalannya waktu maka siswa akan dapat menyukai mata pelajaran tersebut.

Berdasarkan penguasaan materi oleh guru, para siswa, baik dari sekolah umum maupun kejuruan/aliyah yang termasuk ke dalam kategori negeri maupun swasta mereka mengeluhkan hal yang sama. Beberapa hal yang dikeluhkan oleh siswa di antaranya adalah sebagai berikut: a) Dalam proses pembelajaran guru dianggap kurang menguasai mata pelajaran. Hal tersebut disebabkan dalam mengajar guru selalu melihat guru. Sehingga tingkat kepercayaan siswa terhadap guru mulai menurun; b) Menurut siswa selama ini masih banyak guru yang kurang profesionalisme dalam mengajar, sehingga dalam proses pembelajaran terkesan asal-asalan.

Dari berbagai kendala di atas, perlu diadakannya pelatihan khusus terhadap guru, baik dari segi penguasaan materi maupun peningkatan profesionalisme kinerja guru sehingga proses pembelajaran agar dapat berjalan lebih kondusif dan efektif. Apabila semua komponen-komponen di atas mulai dari penerapan metode dalam pembelajaran hingga kurikulum yang sedang dilaksanakan dapat dimaksimalkan oleh guru dalam penerapannya, maka iklim belajar yang kondusif akan terlaksana dengan baik. Dengan demikian akan tercipta pembelajaran yang aktif, kreatif, penuh inovatif, dan menyenangkan. 


\section{Etos kerja dan kesejahteraan guru}

Mengenai kondisi kedisiplinan dan etos kerja para guru SMAN, MA, SMK di Pulau Madura sudah cukup baik. Bentuk kedisiplinan dan etos kerja yang dilakukan para guru berupa: (1) selalu hadir lima belas menit sebelum mengajar, (2) disiplin masuk kelas, (3) melengkapi semua perangkat pembelajaran, (4) kreatif dan inovatif dalam pembelajaran, dan (5) menjalin kerjasama dengan guru mata pelajaran lain.

Dengan adanya kedisiplinan dan etos kerja yang bagus, maka dapat diketahui bahwa para guru memiliki tingkat kesejahteraan yang baik. Hal ini dapat kita lihat juga dari hasil angket yang telah disebarkan. Hasilnya menunjukkan seluruh guru di wilayah Pulau Madura menjawab kondisi mereka baik dan sejahtera serta di atas rata-rata, umumnya yang PNS. Dengan demikian kondisi belajar siswa di sekolah kondusif, lancar dan menyenangkan.

Guru-guru yang ada di SMA Pulau Madura sekotar $80 \%$ memiliki kedisiplinan yang baik. Mayoritas guru yang memiliki kedisiplinan dan etos kerja yang baik adalah mereka, guru-guru yang mengajar di lembaga negeri sedangkan mereka yang mempunyai kedisiplinan yang kurang adalah guru-guru yang berasal dari swasta. Kedisiplinan ini tumbuh karena rasa profesionalitas yang tinggi, yang ada pada guru-guru tersebut. Hal ini terbukti dengan guru datang tepat waktu, cara mengajar yang baik dengan berbagai variasi metode dan strategi pembelajaran, penguasaan materi pembelajaran yang baik, sekaligus pemberian sanksi yang tegas ketika siswa-siswinya melanggar tata tertib yang ada di sekolah. Sejalan dengan kedisiplinan yang dimiliki oleh guru-guru yang ada di SMA Pulau Madura ini, mereka juga memiliki kesejahteraan yang sangat baik. Pengadaan sertifikasi pada guru memberikan semangat tersendiri kepada guru-guru tersebut untuk meningkatkan disiplin kerja. Secara tidak langsung, baik guru negeri ataupun swasta memiliki kesejahteraan yang sama. Banyak aspek yang membuktikan mengenai kesejahteraan yang dimiliki oleh para guru-guru tersebut. Sosialisasi dan kerukunan yang terjalin antar guru di setiap sekolah juga sangat baik.

Guru-guru yang terdapat di MA memiliki kedisiplinan dan etos kerja yang baik dan kesejahteraannya pun bagus, sedangkan untuk kedisiplinan guru-guru MAN yang terdapat di Pulau Madura juga memiliki kedisiplinan dan etos kerja yang sangat baik. Kesejahteraannya juga baik. Tidak terdapat perbedaan yang signifikan dari kedisiplinan dan etos kerja yang terdapat di MA negeri maupun swasta.

Sementara itu, guru-guru yang terdapat di SMK di Madura, baik negeri maupun swasta juga memiliki kedisiplinan dan etos kerja yang baik. Hal ini ditandai dengan tepat waktunya guru-guru masuk untuk memberikan pelajaran kepada siswa di kelas. Tidak hanya itu etos kerja yang ditunjukkan oleh guruguru di SMK ini adalah dengan meningkatkan perannya yaitu membuat pembelajaran menjadi menyenangkan dan mengharuskan siswalah yang aktif dalam pembelajaran. Kondisi tingkat kesejahteraan para guru baik di sekolah SMK negeri maupun swasta juga sudah baik.

\section{Pandangan guru terhadap kurikulum}

Penyikapan kurikulum oleh sekolah rata-rata disikapi dengan baik dan dilaksanakan sesuai dengan sistematika kurikulum yang ada. Kurikulum ini juga dijadikan acuan dalam pelaksanaan proses belajar mengajar. Tentunya penyikapan kurikulum ini tidak hanya dari pihak sekolah, namun dari pihak para pejabat pendidikan di daerah Sumenep itu sendiri. Rata-rata para penjabat pendidikan ini menyikapi kurikulum dengan kurang baik atau kurang diperhatikan. Hal ini dibuktikan dengan banyak sekolah dari jajaran SMA, SMK, maupun MA yang tidak menjawab pertanyaan mengenai tindakan penyikapan kurikulum oleh pejabat pendidikan daerah setempat tersebut.

Dalam kondisi yang sejahtera, kurikulum disikapi dan diperlakukan oleh para guru dengan senang hati. Mereka berusaha menerima, menjalankan kurikulum yang ada, belajar menerapkan kurikulum baru, dan melaksanakan dengan baik dan penuh tanggung jawab. Kondisi seperti ini tidak terlepas dari peran pejabat pendidikan daerah dalam menyikapi dan memperlakukan kurikulum. Hasil 
kuesioner menunjukkan pejabat pendidikan daerah selalu menyampaikan hal-hal yang terkait dengan kurikulum kepada sekolah, mendukung sekolah agar mampu menjalankan kurikulum dengan baik, dan selalu memberikan pengawasan serta berkoordinasi dengan pihak sekolah.

Penyikapan kurikulum oleh sekolah di empat kabupaten di Madura disikapi dengan baik serta disesuaikan dengan kondisi sekolah. Untuk MA (Madrasah Aliyah), kurikulum yang diberikan masih dipilah-pilah dan diolah karena menurut pihak sekolah kurikulum tersebut terlalu cepat dan kurang tepat diterapkan di sekolah jika tanpa adanya modifikasi dari sekolah itu sendiri. Adapun di SMK, kurikulum lebih diberlakukan sesuai dengan prosedur tanpa adanya perubahan meskipun kadang mengakibatkan pembelajaran kurang maksimal. Kurikulum sendiri dijadikan acuan dalam membuat Rencana Pelaksanaan Pembelajaran dan Silabus di daerah Pamekasan, sedangkan di SMA kurikulum disikapi dengan baik seperti di SMK dan diterapkan sebagaimana mestinya, namun ada beberapa kendala, yaitu mata pelajaran yang kekurangan sarana sesuai kurikulum tidak dapat dilaksanakan, sedangkan menurut pandangan pemerintah daerah di bidang pendidikan kurikulum diperhatikan dengan baik namun kurang adanya pengolahan lagi untuk penyesuaian di sekolah-sekolah.

\section{Sarana Prasarana}

Sarana dan prasarana sangat diperlukan untuk menunjang proses pembelajaran. Kualitas sarana dan prasarana akan memberikan dampak yang baik berupa peningkatan prestasi belajar. Akan tetapi, belum semua sekolah mampu memberikan fasilitas yang memadai untuk peserta didiknya. Dari beberapa sekolah di Pulau Madura baik dari SMA, MA, dan SMK secara keseluruhan belum menyediakan fasilitas yang memadai bagi peserta didiknya. Hanya beberapa sekolah tertentu yang telah mampu menyediakan fasilitas secara lengkap. Sekolah-sekolah yang telah menyediakan fasilitas secara lengkap, khususnya sekolah negeri. Penyediaan sarana prasarana tersebut, meliputi: perpustakaan, koperasi, laboratorium, dan lapangan olahraga tersedia dengan baik. Selain itu, pada beberapa sekolah negeri dalam proses pembelajaran telah menggunakan LCD proyektor. Hal ini merupakan salah satu cara yang dapat meningkatkan minat belajar siswa. Karena siswa mengaku merasa senang belajar dengan model presentasi, maupun saat guru menjelaskan dengan menggunakan slide. Sebaliknya, di sekolah-sekolah swasta belum tersedia. Kalaupun ada, jumlahnya terbatas dan tidak mencukupi untuk seluruh kelas.

Di MA, khususnya swasta masih belum dimiliki laboratorium karena kegiatannya lebih difokuskan untuk pembangunan fasilitas agama seperti pembelian alat musik hadrah, dan lain-lain yang menunjang untuk kegiatan keagamaan. Namun ada salah satu sekolah di Pulau Madura yang memiliki sarana prasarana yang kurang sekali. Sekolah ini memiliki gedung yang bisa dibilang kurang layak karena rusak. Fasilitas yang ada juga kurang karena untuk melaksanakan pembelajaran multimedia dirasa kurang sekali.

Kondisi perpustakaan dan proporsi buku siswa MA di Pulau Madura kurang memadai, khususnya sekolah swasta. Buku yang terdapat di perpustakaaan ini masih tergolong sedikit dibandingkan dengan jumlah siswa yang belajar di sekolah tersebut. Pada tingkat SMK dan SMAN, kondisi perpustakaan dan proporsi buku siswa sudah memadai, buku-buku pokok sudah cukup dengan jumlah siswa. Selain itu di perpustakaan juga terdapat banyak buku-buku penunjang (baik fiksi maupun non fiksi) sehingga membuat siswa lebih suka membaca buku di perpustakaan. Di samping itu, kualitas buku pelajaran yag digunakan juga sudah sangat bagus.

Secara umum sekolah-sekolah di Pulau Madura telah mampu menyediakan sarana dan prasarana dengan baik. Hanya saja untuk kualitas sarana tersebut masih bergantung dengan kualitas sekolah itu sendiri. Sekolah yang sangat baik mampu pula menyediakan fasilitas yang sangat baik. 


\section{Analisis mengenai iuran yang dibebankan ke orang tua/wali siswa}

Di beberapa SMA yang ada di Pulau Madura, iuran yang dibebankan kepada orang tua/wali siswa tidak memberatkan. Uang SPP atau uang iurannya gratis sehingga tidak memberatkan. Namun karena tidak adanya iuran yang dibebankan kepada orang tua, bukti nyata pembangunan pun tidak ada. Tidak adanya iuran atau SPP membuat sekolah-sekolah SMA yang ada di Pulau Madura tidak ada perkembangan. Penentuan besarnya iuranpun tidak ada musyawarah dengan pihak orang tua siswa. Tidak adanya musyawarah dengan pihak sekolah membuktikan bahwa hubungan antara orangtua dan guru-guru SMA di Pulau Madura ini kurang baik. Harusnya terdapat sosialisasi mengenai penentuan biaya iuran yang akan dibebankan pada orang tua. Kebijakan mengenai penentuan besarnya iuran kepada orang tua siswa sepenuhnya berada di tangan sekolah.

Rata-rata uang iuran yang dibebankan kepada orang tua sama sekali tidak memberatkan orang tua. Uang iuran yang harus dibayar oleh orang tua $60 \%$ menunjukkan bahwa adanya perkembangan pada pembangunan yang ada di sekolah tersebut. Namun, $40 \%$ sekolah MA baik negeri maupun swasta tetap tidak mengalami perkembangan. Kondisi sekolah dan sarana serta prasarana yang terdapat di sekolah tersebut tetap sama saja. Penentuan besarnya iuran yang harus dibayar oleh orang tua tidak ditentukan secara musyawarah antara orang tua dengan pihak sekolah, sehingga penentuan tersebut sepenuhnya berada di tangan sekolah.

Biaya SPP untuk SMK swasta lebih murah dibandingkan dengan SMK negeri, sehingga untuk iuran yang dibebankan kepada orang tua untuk SMK negeri dinilai memberatkan. Orang tua beranggapan bahwa uang iuran yang dibebankan masih terlalu mahal dan tidak sesuai dengan pendapatan orang tua, sedangkan untuk SMK swasta dinilai tidak memberatkan dari segi iurannya karena orang tua beranggapan bahwa pembebanan iuran pada SMK negeri masih lebih mahal. Meskipun uang iuran yang dibebankan oleh sekolah hanya sedikit. Namun, bukti nyata berupa perkembangan sekolah sudah mulai meningkat. Meskipun perkembangannya secara perlahan namun perkembangan ini konsisten. Salah satu bukti dari perkembangan pembangunan sekolah yang bertambah bagus adalah adanya kelas baru dan perpustakaan baru. SMK negeri pun juga memiliki perkembangan yang membuat sekolah menjadi lebih baik. Penentuan besarnya iuran yang diberikan kepada orang tua berdasarkan kesepakatan bersama antara pihak sekolah dengan orang tua siswa.

\section{Simpulan}

Untuk meningkatkan mutu pendidikan di Pulau Madura tidaklah mudah. Para guru SMA/SMK/MA harus mendapatkan pelatihan mengenai pembelajaran yang inovatif. Guru SMA lebih memilih pengembangan pada profesionalisme selain mengajar dalam kelas dengan melakukan penelitian tindakan kelas, penulisan artikel maupun karya ilmiah. Guru SMK lebih memilih mengembangkan kompetensi keahlian yang telah dimiliki, sehingga menambah pengetahuan dan lebih menguasai materi yang akan diajarkan. Pada guru MA, para guru lebih memilih pelatihan yang bertujuan untuk mengembangkan pembelajaran yang menarik serta pelatihan dapat memberi mereka wawasan tentang perkembangan ilmu pengetahuan saat ini. Adapun mismatch atau guru yang mengajar mata pelajaran yang tidak sesuai dengan latar belakang kualifikasi pendidikannya. Kebanyakan guru merangkap mata pelajaran pokok (sesuai dengan klasifikasinya) dengan mata pelajaran pilihan (muatan lokal).

Penyikapan kurikulum oleh sekolah rata-rata disikapi dengan baik dan dilaksanakan sesuai dengan sistematika kurikulum yang ada. Kurikulum ini juga dijadikan acuan dalam pelaksanaan proses belajar mengajar. Tentunya penyikapan kurikulum ini tidak hanya dari pihak sekolah, tetapi dari pihak para pejabat pendidikan di Madura.

Sarana-prasarana yang disediakan sekolah untuk menunjang proses pembelajaran yang berlangsung di sekolah secara umum lengkap dan sangat mendukung. Hal ini dapat ditemukan di sekolah-sekolah negeri. Akan tetapi, di sekolah-sekolah swasta masih perlu penambahan sarana-prasarana untuk menunjang pembelajaran. 
Di sekolah swasta maupun sekolah negeri baik yang kejuruan maupun non kejuruan, iuran pendidikan masih diberlakukan dan dibebankan kepada orang tua dan sebagian besar orang tua merasa tidak merasa keberatan. Besarnya iuran ditentukan tidak melalui rapat dengan orang tua/wali siswa, tetapi ditentukan sekolah. Hal inilah yang menyebabkan orang tua keberatan karena tidak terlibat langsung dalam pengambilan keputusan.

\section{Daftar Pustaka}

Irianto YB (2011) Kebijakan pembaruan pendidikan, konsep, teori, dan model. Jakarta: Rajawali Pers. Mastuhu M (2007) Sistem pendidikan nasional visioner. Tangerang: Lentera Hati.

Minarti S (2011) Manajemen sekolah, mengelola lembaga pendidikan secara mandiri. Yogyakarta: Ar-Ruzz Media.

Mulyatingsih E (2012) Metode penelitian terapan bidang pendidikan. Bandung: Alfabeta.

Rohiat (2009) Manajemen sekolah: teori dasar dan praktik. Bandung: Refika.

Umiarso dan Gojali I (2010) Manajemen mutu sekolah di era otonomi pendidikan. Yogjakarta: IRCiSoD. 